\title{
DEKONSTRUKSI CERITA ABSURD NUKILA AMAL
}

\author{
Pepen Priyawan \\ Dosen Bahasa dan Sastra Inggris Fakultas Adab dan Humaniora \\ UIN Sunan Gunung Djati Bandung \\ pepenpriyawan@gmail.com
}

\begin{abstract}
ABSTRAK
Teks sastra berkait dengan membaca secara dekonstruktif. Cerpen berjudul Hari Anya Jatuh Cinta dan Syam karya Nukila Amal (2010) bisa dibaca dengan menekankan wacana dekonstruksi. Berdasar pada wacana dekonstruksi, narasi dan relevansi antara keduanya kata dalam narasi Hari Anya Jatuh Cinta bisa meninggalkan kenyataan dan regularitas makna dan absurdisme mengalir berdasar pada kepercayaan ke-tak berarti-an pada dunia regulasi narasi dan konsep difference yang menjadi efek permainan konsep atau kata untuk sebuah perwujudan verbalisasi dan nominalisasi. Aktifitas teori poststruktural seperti ini ketika diterapkan terhadap cerpen bisa menggambarkan diskusi teoretis dan metodologis. Narasi akan dikonfirmasi ulang dengan pembacaan terhadap teks secara dekonstruksi. Narasi dipaparkan secara analisis dekonstrutif, dielaborasi dan terintegrasi dengan simbol dalam bentuk kata dan bahasa. Lalu penjelasan selanjutnya akan diarahkan pada regularitas makna, dan ke-tak berarti-an pada regulasi narasi dan konsep difference yang menjadi konsepsi efek permainan konsep atau kata untuk sebuah perwujudan verbalisasi dan nominalisasi.
\end{abstract}

Kata Kunci: Dekonstruksi, Cerita Pendek, Nukila Amal, difference, Relasi Makna

\section{PENDAHULUAN}

Dalam dua buah teks cerpen berjudul Hari Anya Jatuh Cinta dan Syam karya Nukila Amal (2010) terdapat sejumlah unsur yang berkaitan dengan wacana dekonstruksi dan postrukturalisme. Unsur-unsur keduanya ini berkenaan dengan perihal difference (membedakan), difference (menunda), trace (jejak), decentering (Struktur tanpa pusat dan hirarki), logosentrisme (pemikiran yang mengarahkan adanya satu pusat), dan interteks (hubungan/jalinan antar teks).

Cerpen berjudul Hari Anya Jatuh Cinta karya Nukila Amal (2010) ini sendiri memiliki narasi lewat tokoh utamanya, Anya. Narasi yang cukup bermuatan wacana dekonstruktif cerpen adalah

"KBY LAMA SENAYANTUHAN Bersamamu-TARIF LAMA- Boruku NaburjuDIKONTRAKAN_Available Now!!-MANTAP BENEERRLAS KETOC MAGICKEBERSIHAN ADALAH TANGGUNG JAWAB KITA BERSAMA —obat perkasaFRED CHIKEN-Jeep-LAJUR KIRI KHUSUS BUS-Abang jarang pulang-Win Bali Trip PEJABAT DI NEGERIKU SUKA KORUPSI-JL. PIRUSZAKAT PEDULI UMATBaDuT SULAP_Pasrah tapi tak 
rela-JASA DOCUMENTKLINIK BUKA 24 JAMSOMEDAY LAUNDRY SERVICE-Buronan MertuaGOOD BLESS YOU-Warung RELA NGETOP-CUCI SOFA - Join! You will meet strange people!-BUBUR KACANG IJO - CANOPI CAIN" Atau juga lewat penokohan dalam cerpen Syam.

"SYAM, tak seperti namanya, bukan seorang matahari. Ia antitesis cahaya dan segala yang terang. Semisal lukisan, ia bukan figur di tengah yang terangbenderang berdiri gagah berkacak pinggang, namun siluet gelap berjubah hitam yang bersandar di sudut. Siluet yang mengamati segala di sekitar, di dalam dan di luar lukisan."

Wacana yang dimaksud dalam pasase-pasase ini bisa terkait dengan dekonstruksi lewat tokoh dan kepenulisan. Bentuk huruf dan bunyi dalam sebuah teks sastra tak perlu bermakna. Simbol dalam bentuk kata dan bahasa mungkin bisa merupakan pertemuan antara sigifier dan signified. Namun benarkah kedua konsep ini pun berhubungan dan bermakna dalam pasase ini. Hurufhuruf dalam kata-kata dan narasi muncul tak bermakna untuk memandu, untuk menjadi informasi, menjadi patokan, dan bahkan untuk menjadi nilai. Tak ada satupun huruf yang menguasai dirinya sendiri, atau kata-kata yang dibentuknya. Kata dalam teks bisa mengabaikan regulasi makna. Kata meninggalkan kenyataan dan regularitas makna yang dimaksudkannya. Kemudian absurdisme mengalir berdasar pada kepercayaan ke-tak berarti-an, walau pada dunia regular narasi. Namun kemudian semua adalah narasi.
Namun jika kata dan makna berhubungan maka sebenarnya sedang berlangsung proses pemaknaan itu sendiri. Namun menulis itu memberlakukan kuasa dan relasi-relasi kuasa yang terbaca, berbunyi, dan menuntut makna. Difference menjadi konsepsi efek permainan konsep atau kata untuk sebuah perwujudan verbalisasi dan nominalisasi.

Cerpen ini bercerita mengenai absurditas pada sebuah latar kota. Anya dalam kesehariannya bergelut dengan pekerjaan dan rutinitas. Dalam satu hari penceritaan, Anya memiliki wacana yang membingungkannya. Anya diceritakan lupa pada hari Minggu, hari libur dari rutinitas dan kerjanya. Ia tetap pergi ke kantor. Di sepanjang perjalanannya ia menemukan keganjilan atas segala yang ia baca. Cerita ini absurd dengan segala tulisan yang Anya baca di sepanjang perjalannya menuju kantor. Kemudian lewat segala hal yang tertulis dan terbaca ini ia membuat narasinya sendiri, dalam kertas-kertas yang terserak di dalam mobilnya.

Beberapa penelitian terdahulu terkait dengan penelitian ini telah dilakukan oleh beberapa peneliti. Dari sejumah disertasi yang terbaca, ada makalah dari Purwanto berjudul Wisanggeni Sang Buronan dalam Perspektif Dekonstruksi (2011) mengenai cerita pusat dan cerita pinggiran. Cerita pinggiran ini adalah cerita yang dibuat karena dipicu oleh sebuah narasi besar yang sudah ajeg. Lewat sebuah novel berjudul Wisanggeni Sang Buronan (2011) pandangan dekonstruksi teks dianggap tidak stabil sehingga narasi harus dibaca dengan strategi dekonstruktif. Tokoh dan narasi Wisanggeni tidak pernah terkisahkan dalam Mahabharata. Namun, tokoh dan cerita Wisanggeni ini 
dikisahkan dalam jagad pewayangan Jawa. Wisanggeni sebagai tokoh sekaligus narasi telah mengubah pakem kisahan Mahabharata. Wisanggeni mengada (come into being) dari yang sebelumnya tidak ada. Wisanggeni versi Adjidarma dalam narasi pewayangan Jawa juga mengalami dekonstruksi karena berbeda pakem kisahannya dalam pewayangan Jawa.

Dekonstruksi terhadap pakem narasi Mahabharata muncul pada saat narasi Wisanggeni Sang Buronan hadir sebagai teks. Seperti yang sudah disebutkan Mahabharata tidak pernah mengenal tokoh bernama Bambang Wisanggeni sehingga narasi Wisanggeni pun berarti tidak ada karena tak pernah diceritakan. Mahabharata versi India berada dalam atau sebagai logosentrisme: pikiran yang mengarahkan adanya satu pusat.

(2009) Penelitian lain, Mardiana

Dekonstruksi Derrida Terhadap Sistem Stratifikasi Sosial Bali Dalam Karya-Karya Oka Rusmini (2009). Ia mengungkapkan mengenai perihal dekonstruksi langsung lewat penerapan analisis dari tokoh pionir deonstruksi, Jaques Derrida. Dalam analisisnya konflik stratifikasi sosial di Bali menjadi permasalahan oleh Oka Rusmini. Sistem stratifikasi sosial tersebut dikritisi sedemikian rupa melalui alur cerita yang menarik dan lewat pendekatan dekonstruksi. Dekonstruksi dijadikan pendekatan dalam penelitian lewat jejak-jejak tanda yang terdapat dalam narasi. Representasi dekonstruksi terhadap sistem stratifikasi sosial Bali terdapat dalam keseluruhan karya Rusmini.

Lewat penelitian lain, dekonstruksi dalam analisis berjudul Dekonstruksi Nilai-Nilai Keluarga Dalam Film Noir tulisan Adrian Jonathan Pasaribu memberikan gambaran teks lain. Teks dari sebuah genre film noir dijadikan anomali. Dengan segala variasinya tentang misteri pembunuhan dan perselingkuhan rumah tangga. Dalam perspektif yang lebih makro, film noir tidak menjadikan rumah dan keluarga sebagai solusi konflik cerita, yang sebelumnya merupakan tradisi bercerita mayoritas film-film keluaran Hollywood.

Keluarga sebagai agen dari perkembangan ekonomi yang menghidupi dirinya sendiri. Keluarga sebagai unit produksi yang ideal adalah keluarga yang setiap anggota keluarganya mampu memperoleh pemasukan yang lebih besar ketimbang pengeluaran finansialnya. Konsekuensi dari industrialisasi bagi kehidupan keluarga adalah keluarga menjadi semakin kecil. Keberadaan industri memindahkan kerja dari rumah tangga ke pabrik dan kantor. Konsekuensinya: ukuran keluarga ditekan sekecil mungkin, sehingga bujet untuk mengurus keluarga tidak melebihi penghasilan yang diterima dari tempat kerja. Model keluarga, dimana suami sebagai pencari nafkah dan istri sebagai pengatur keluarga, adalah model keluarga yang kemudian banyak ditemukan di keluarga-keluarga Amerika Serikat pasca perang. Model keluarga yang serupa dapat ditemukan dalam film noir, yang juga berkembang dalam periode yang sama. Dalam penelitian ini, film noir berarti dilihat sebagai cerminan dari apa yang terjadi di lanskap sosial jamannya.

Berdasarkan pada latar belakang, selanjutnya penelitian dirangkai dengan menekankan pada wacana dekonstruksi. Penelitian ini akan menyertakan pendekatan dan metode poststrukturalisme, terutama 
dari Derrida dan Foucault. Berdasar pada huruf-huruf dalam kata-kata dan narasi kemunculan makna memandu, untuk menjadi informasi, menjadi patokan, menjadi nilai. Padahal tak ada satupun huruf yang menguasai dirinya sendiri,atau katakata yang dibentuknya. Kata dalam teks tidak selalu harus menjadi regulasi makna. Kata dan makna berhubungan hanya ketika ada makna dan sebenarnya ketika pemaknaan terjadi makan sedang berlangsung proses pemaknaan itu sendiri, dalam benak manusia. Menulis sendiri memberlakukan kuasa dan relasi-relasi kuasa yang terbaca, berbunyi, dan menuntut makna. Dari wacana kata, makna, relevansi dan pertimbangan hubungan-hubungan kata dan makna maka penelitian ini, dengan memperhatikan objek cerita pendek Hari Anya Jatuh Cinta, mempersoalkan beberapa relevansi atas hal-hal di atas.

1. Bagaimana kata dalam narasi Hari Anya Jatuh Cinta meninggalkan kenyataan dan regularitas makna?

2. Bagaimana absurdisme mengalir berdasar pada kepercayaan ketak berarti-an walau pada dunia regular narasi dan difference menjadi konsepsi efek permainan konsep atau kata untuk sebuah perwujudan verbalisasi dan nominalisasi?

Narasi dalam penelitian ini merupakan wacana teknis. Hal-hal teknis di dalam sebuah narasi bergerak dalam sebuah proses kegiatan. Seperti halnya gerakan maka sebenarnya ada penggerak narasi ini. Pada akhirnya keberlangsungan narasi bergantung pada komponen-komponennya. Kesastraan lewat perangkat yang begitu terstruktur bisa memberikan wacana narasi. Sebagaimana rumusan masalah di atas tujuan dari kegiatan penelitian ini untuk:

1. memahami kata dalam narasi Hari Anya Jatuh Cinta meninggalkan kenyataan dan regularitas makna, dan

2. memahami absurdisme mengalir berdasar pada kepercayaan ketak berarti-an walau pada dunia regular narasi dan difference menjadi konsepsi efek permainan konsep atau kata untuk sebuah perwujudan verbalisasi dan nominalisasi

Terdapat beberapa kegunaan yang diharapkan dalam penelitian ini, kegunaan tersebut sebagaimana secara teoretis bisa memberikan pembelajaran dan penelitaian atas narasi sebagai teks sastra juga berarti memahami aktifitas dekonstruksi. Aktifitas teori poststruktural ini ketika diterapkan terhadap teks cerita pendek bisa menggambarkan diskusi teoretis dan metodologis. Kegunaan penelitian secara praktis: pertama, di dalam penelitian ini akan terkumpul beberapa pemahaman yang bisa saling menopang dan memberi contoh bagaimana membaca narasi dengan cara membaca secara dekonstruktif dan kedua, berdasarkan hasil penelitian, penelitian ini akan memberi pemahaman bagaimana dekonstruksi dan posstrukturalisme bisa dipahami di dalam narasi.

Objek penelitian ini adalah dua buah cerpen karya Nukila Amal berjudul Hari Anya jatuh Cinta dan Syam. Publikasi terakhir novel yang dijadikan sumber bacaan dan penelitian ini diambil dari kumpulan cerpen Nukila Amal yang diambil lewat kumpulan cerpen Kompas yang diunduh dari situs kumpulan cerpen Kompas. 


\section{Metode}

Penelitian ini menggunakan metode deskriptif analisis. Secara deskriptif, analisis ini menggunakan perangkat latar dan penokohan untuk mengungkap absurditas. Dengan penggunaan metode deskriptif analisis, penelitian ini mendeskripsikan fakta-fakta yang kemudian dianalisis. Eagleton (1996: 2-3) menegaskan bahwa bahasa merupakan fakta material yang fungsinya dapat dianalisis seperti seseorang menguji sebuah mesin. Bahasa terbuat dari kata, bukan objek atau perasaan, dan salah jika melihatnya sebagai ekspresi dari pemikiran penguasa tulisan.

$$
\text { Eagleton (1996: }
$$

menegaskan bahwa wacana berarti satuan bahasa terlengkap yang direalisasikan dalam bentuk karangan atau teks. Wacana membuat tokoh berlaku dengan menandai posisi tertentu dari subjek individual yang menciptakan identitasnya. Kemudian Eagleton (1996: 2) mengatakan bahwa kritisisme seharusnya memisahkan seni dari misteri dan memberikan perhatian atas seni dengan bagaimana teks sastra bekerja. Sastra bukan pseudo religi atau sosiologi melainkan organisasi khas atas bahasa. Bahasa memiliki hukumnya sendiri, struktur dan perangkat yang dipelajari lewat bahasa itu sendiri. Bahasa tidak bisa direduksi kedalam hal yang lainnya. Karya sastra bukan kendaraaan ide-ide atau cerminan realitas sosial atau juga bukan penjelmaan kebenaran transendental.

Sebagaimana dekonstruksi memberikan langkah-langkah dengan cara pembacaan lewat sudut pandang yang lain. Metode pembacaan dari sisi atau sudut pandang lain ini terurut dengan langkah: mentukan oposisi biner dari kata yang menjadi kode, menentukan mana oposisi yang lebih unggul, mendekonstruksi oposisi ini dengan mencari segala sesuatu yang bertentangan atau melemahkan. Tujuannya untuk mencari pertentangan internal antara oposisi biner tersebut sehingga bisa ditentukan tema yang lebih unggul dari yang lainnya. Dengan kata lain, walaupun pembaca tidak terlatih untuk melihat hal seperti ini, teks itu sendiri akan mendekonstruksi dirinya sendiri, dan menenentukan pengaruh dari ketiga hal di atas.

\section{HASIL PENELITIAN DAN PEMBAHASAN \\ Dekonstruksi Cerita Absurd Nukila Amal}

Sejumlah paparan dielaborasi dan terintegrasi mengenai simbol dalam bentuk kata dan bahasa dalam narasi yang merupakan pertemuan antara sigifier dan signified. Lalu penjelasan selanjutnya akan diarahkan sesuai analisis dekonstruktif atas kata dalam narasi Hari Anya Jatuh Cinta dan Syam, karya Nukila Amal, yang meninggalkan kenyataan dan regularitas makna. Terakhir, analisis memaparkan absurdisme yang mengalir berdasar pada kepercayaan ke-tak berarti-an pada regulasi narasi dan konsep difference yang menjadi konsepsi efek permainan konsep atau kata untuk sebuah perwujudan verbalisasi dan nominalisasi.

Tahun '70-an memunculkan karya-karya sastra yang lain dari sebelumnya yang dimana tidak menekankan pada makna kata yang kemudian digolongkan ke dalam jenis sastra kontemporer. Dalam Kamus Besar Bahasa Indonesia 
(KBBI) sastra kontemporer adalah sastra yang hidup pada masa kini atau sastra yang hidup dalam waktu yang sama dan sastra yang berusaha bergerak mendahului zamannya. Sastra Indonesia Kontemporer diartikan sebagai sastra yang hidup di Indonesia pada masa kini atau sastra yang hidup di Indonesia pada masa mutakhir atau sastra yang hidup di Indonesia pada zaman yang sama. Dalam bentuk cerita pendek kontemporer muncul tidak selalu mengikuti pola cerita-cerita pendek yang ada, tetapi mereka berusaha menemukan pengucapan diri dengan inovasi yang matang.

$\begin{array}{cc}\text { Sastra } & \text { kontemporer } \\ \text { merupakan bentuk seni yang }\end{array}$
mengobrak-abrik tatanan bahasa atau kata. Ciri cerpen kontemporer membentuk penyajian yang kadang tidak lazim dan berbeda dari cerita pendek pada umumnya. ciri anti logika, dalam arti kadang menyalahi dasar logika manusia pada umumnya. Apa yang menjadi isi cerita jauh dari kenyataan hidup yang sebenarnya. Sering mengabaikan plot dan alur cerita. Maksudnya sama sekali tidak terikat pada pola urutan konvensional; pembukaan - klimaks - antiklimaks - penutup. Melainkan lebih bebas, bisa berbentuk zigzag, saling silang, dan sebagainya. Bersifat serba aneh atau absurd-identik dengan absurdisme. Karena krakteristik seperti alur dan peristiwa kadang tidak jelas, tidak menentu, bahkan tidak rasional. Anti tokoh, atau tidak mengindahkan masalah jelas atau tidaknya tokohtokoh di dalamnya. Tokoh yang ada dalam cerita pun lahir dari imajiner (pengimajian), khayalan, dan sebagainya. Khusus dalam tema realitas kehidupan, selalu bersifat kompleks dan terasing. Melukiskan detail, insiden dan situasi secara multi (tidak fokus pada satu emosi dan impresi), serta menimbulkan efek dan kesan yang majemuk. Nukila Amal lahir di Ternate, Maluku Utara, kini bermukim di Jakarta. Novelnya adalah Cala Ibi (Pena Klasik, 2003) dan kumpulan cerita pendeknya Laluba (Alvabet, 2005). Narasi kota dan kesemrawutannya menjadi pokok yang kerap dipersoalkan. Sejumlah narasi seringkali memaparkan bagaimana seseorang memandang dunia dalam kesendiriannya.

\section{Telaah Hari Anya Jatuh Cinta}

Jatuh cinta merupakan perjumpaan. Anya berjumpa dengan banyak hal dalam bentuk huruf dan bunyi. Tak ada yang bermakna dalam perjumpaan ini. hanya ada kegilaan, keisengan, dan keseksian kesadaran atas sebuah dunia baru. Dunia sisi-sisi kertas, waktu akhir pekan, diluar tatanan. Mungkin jatuh cinta itu ada pada pandangan pertama. Anya terpikat pada suatu bentuk yang tak perlu berfungsi; walau sebenarnya hal tersebut bisa berfungsi. Atau pada dasarnya halhal tersebut sudah berfungsi. Akan tetapi saat akhir pekan fungsi harus diubah menjadi bentuk lain yang tak berfungsi. Semacam perjumpaan manusia dengan liburan, yang juga di akhir pekan, yang tak perlu berfungsi dalam kehidupan kecuali liburan hanya bentuk di luar keseharian pekerjaan di hari-hari normal sebelumnya.

"PAGI itu Anya "tak menatap cermin.

Cermin menjadi symbol pertemuan. Awal dari narasi memperhatikan fungsi yang tak berfungsi. Cermin bisa menjadi 
teladan dan bisa memberikan bayangan dari perasaan hati. Namun keteladanan atas bayangan tidak bisa memulai hari anya.

"Dari kamarnya ia berlari menuju dunia luar, berkejaran dengan waktu."

"Di perempatan pertama ketika lampu menyala merah, ia bersandar. Dengan agak berhatihati, Anya memiringkan kepalanya ke kiri dan kanan, menggoyangkan kepala dengan senang; terasa begitu ringan, nyaris seperti ada yang tak beres di dalam sana.

Anya tertawa. Ia merasa dirinya seolah akan lepas. Seakan ada sepasang sayap ringan sedang mengembang, mungkin di punggungnya, mungkin di kaki, di tangan, atau di jari-jari. Di manapun berada, seakan sayapsayap itu sedang berkibas-kibas, siap melesat terbang."

Ada hal yang dilepaskan Anya. Kegilaan yang biasa dikekang kini bisa ia miliki. Kebebasan atas belenggu rutin ia anggap sederhana. Rasanya kita masih harus menjalankan pembebasan: membebaskan diri dari tendensi jadi robot, membebaskan diri dari ketakutan kepada kata yang berarti dan membebaskan diri dari proses kehilangan arti (Goenawan Muhamad). Kesenangan merupakan prinsip dari kegialaan. Ketika aturan dibuat untuk bertindak dan berlaku kini hanya bagian dari tertawaan. Tidak ada yang memandu dari segala hal yang tertulis. Semua hanya bagian dari kesenangan. Keisengan.

"Betapa pagi itu huruf-huruf menyergap mata menebar pesona."

Huruf-huruf ini muncul sebagai huruf saja. bukan kata yang bermakna untuk memandu, untuk menjadi informasi, menjadi patokan, menjadi nilai. Mereka semua hanya huruf yang tidak lagi mengekang. Tidak lagi harus dimaknai. Semua muncul terbaca tanpa beban. Namun huruf menarik karena tak "berjiwa". Tak ada satupun huruf yang menguasai dirinya. Karenanya mereka semua harus menjadi huruf. Tidak boleh menjadi kata-kata, karena kata bermakana dan artinya mengekang. Regulasi harus diabaikan kali ini.

"Anya mengerjap-ngerjapkan mata."

Aksi ini harus dilakukan karena masih ada kesadaran dalam diri Anya. Ia masih berada dalam realitas yang menghukum. Kesalahan apapun jika dilakukan adalah hukuman akibatnya. Yang bisa memuaskan dan menghilangkan realitas sejenak adalah membaca huruf.

"Ada yang terasa genting.... Tibatiba ada suara klakson panjang, terdengar begitu dekat. Anya membuka mata, reflex menginjak pedal rem. Chevrolet. Hanya sedikit celah bersisa dengan pantat mobil yang ngerem mendadak di depannya. Jantung Anya berdebardebar oleh kecelakaan yang tak jadi".

Kegilaan ini harus berhenti. Anya berusaha kembali pada arus kesadaran. Arus kenyataan dan realitas yang sangat membahayakan. Sejenak ia kembali pada kesadaran atas tubuh. Atas seksualitas mungkin?

"Ia terlambat sejam lebih, hampir setengah sepuluh saat memasuki pelataran parkir."

Bagian ini pun penting. Karena Anya telah begitu terlena meninggalkan kenyataan dan regularitas. Satu jam waktu yang lama untuk menikmati kegilaan. 
"Pak Satpam datang menghampiri saat ia memarkir mobil. Anya menyambar tas, keluar dari mobil dengan agak terhuyung. Tatapannya berputar menatap pelataran parkir dengan bingung, lalu menatap Pak Satpam yang juga menatapnya dengan bingung, datang menghampiri sambil mendencing-dencingkan segepok kunci. Hasan."

Satpam menjadi penanda atas ke-takberlakuan hukum atas dirinya. Hasan hanya ataupun satpma hanya kat yang tak bermakna namun ia ada. Bukan satpam atau hasan yang penting. Hasan ada untuk menjadi tumpuan kehausan atas ke-takbermaknaan. Oleh karennya ia hanya menanyakan "Kemana orang-orang, mobil-mobil, motor-motor, helmhelm?"

"Hasan. Bapak. Kenapa begini kosong, Pak? Kemana orang-orang, mobil-mobil, motor-motor, helmhelm?"

"Nggak ada orang hari ini. Ibu mau lembur?"

"Lembur? Ini hari apa?"

"Hari Sabtu."

"Ooo? Terus ngapain saya buruburu lari-lari sampai hak sepatu patah sebelah? Ini, lihat, Pak." Anya mengangkat kaki kirinya, sejenak menyilangkan kaki di lututnya untuk menunjukkan bukti sol sepatu. "Khilaf rupanya. Kalau begitu saya bisa lembur menulis. Saya semalam berniat melanjutkan dua prospektus, tenggatnya seminggu lagi."

Absurdisme mengalir berdasar pada kepercayaan ke-tak berarti-an. Semua hal harus tidak masuk akal. Tata tertib menyadarkan bahwa semua berbenturan satu sama lain dengan kepentingan lain, dan bagi masyarakat lain.
"Menulis yang bukan prospektus..." Anya tersenyum senang, membayangkan prospek hari yang membentang di hadapan. Prospek jok kursi mobil untuk bersandar. Kertas-kertas.... Hurufhuruf...."

Kembali kepada dunia absurd dan kembali pada dunia regular adalah bagian narasi yang disajikan. Hanya yang lebih mengemuka, absurditas bisa terlaksana dan mengejawantah karena hari ini hari sabtu. Akhir minggu memang seharusnya waktu ketika manusia meninggalkan normalitas.

"Anya ingat untuk menurunkan kakinya sambil berkata cepat. "Tapi, bapak diam-diam menyadari bukan, kalau saja para staf yang datang lembur di hari Minggusengaja atau tidak-niscaya perusahaan kita kian berjaya, berdenyut-denyut dengan revitalisasi bisnis. Ekonomi, mikro dan makro. Para staf perusahaan sekuritas ini, seperti Bapak ini, akan senang dalam security. Lembur Hari Minggu, tak ada kerumunan staf, distraksi, kontradiksi, presentasi, cuma AC sepoi-sepoi.... Beberapa yang juga patut dipuji adalah yang pulang jam dua malam, atau yang bawa pulang berkas ke rumah karena kalau pulang malam dia takut kena marah istri atau mertua — tadi saya bilang apa?"

Satpam bernama hasan ini sosok yang cocok untuk perjumpaan atas kegilaan. Karena dalam sosok sekuritas ini biasanya disiplin dan hukuman menjadi regulasi seharihari. Menjaga adalah regulasi. Bahkan di akhir pecan pun regulasi tetap berjalan. Anya sadar atas keadaan regularitas ini. anya menemukan contoh ideal betapa 
sosok inilah yang paling bisa memenuhi regularitas keseharian untuk rutinitas atau prospectus, bagian pekerjaan yang harus anya buat dalam dunia nyata. Waktu akhir pecan, sosok satpam, dan perjumpanperjumpaan atas huruf-huruf, serta kegiatan menulis merupakan relasi yang bisa menghubungkan anya atas kegilaan; tempat dimana kebenaran dan kekuasaan istrihat sejenak untuk menguasai dirinya.

"Baru kuperhatikan, hari ini banyak sekali huruf-huruf di Jakarta. Bertampang terang, siaga dan awet muda. Ada di segala permukaan sampai ke celah dan ceruk terdalam, bersitahan di bawah tatapan manusia. Patuh dan tak lelah, seperti sekompi prajurit. Apa sudah dari dulu mereka begitu? Bikin orang tak memperhatikan lalu-lintas. Di sana huruf di sini huruf. Aku curiga banyak dari mereka adalah huruf2 pendatang atau pelancong. Tapi aku khawatir huruf2 pelancong itu akan tinggal di kota ini selamanya, jadi penghuni ilegal. Begini, aku senang api-masalahnya aku senang tapi sebal, kenapa kota ini khususnya suka huruf2 besar. (Apa karena ini ibukota? Kapital? Maka suka hurufhuruf kapital. Sebab seperti aku, ini kota kapitalis, makanya gemar berdagang.)

Ajaib: huruf2 di luar sana dan di dalam sini. Tadi pagi aku tulis surat untuk papa. Sebenarnya masih bisa lebih panjang. Dalam tulisan cukup indah, tanpa bahasa sms, bertata bahasa rapi seperti papa. Mengingat pelajaran abjad papa. Menulis dan membaca."

"Abcdefghijklmnopqrstuvwxyz"

Banyak hal yang tak perlu bermakna namun sebenarnya mereka berhubungan. Bukankah jika berhubungan maka sebenarnya sedang berlangsung proses pemaknaan itu sendiri. jikapun bermakna maknanya karena hubungan-hubungan itu sendiri. Juga termasuk huruf kapita dan keadaan kota Jakarta yang begitu semrawut swemuanya. Tidakkah harus bermakna dan berhubungan semuanya? Sekali lagi ketika berhubungan dan bermakna semuanya hanya ada dalam relasi saja.

"Kupukupuku.

(Aku punya rahasia: aku begitu gesit pagi ini, rasanya seperti kupu-kupu. Seperti ada sayap tumbuh sepasang. Tadi-kalau tidak pegangan-aku hampir bisa tahu apa rasanya jadi kupu-kupu, sayap mengibas2seperti menguji kepekatan udara dan gaya tarik bumi. Ini pasti dapat dengar dari Animal Palnet. Planet. Mungkin sepasang sayap baruku tumbuh di jari2. Ya, rasanya begitu. Kupu-kupu badai berpusing, tercipta dari ketiadaan, milikku seorang. Kupu-kupuku memberkahi setiap kata, setiap ruang putih di antara. Aku seperti percaya kupu-kupu dan huruf-huruf akan membawaku terbang jauh memasuki segala benak.)

Saatnya keluar main, wahai huruf-huruf! Huruf-hurufku berlesatan keluar di ujung bolpen, seregu, serombongan, oh berbondong-bondongan.

(Berbondongan?) Mendarat gembira pakai parasut tinta biru, sana-sini jebrat-jebret jadi sederet. Hari ini cerah, silakan bawa kursi malas, pakai kacamata hitam penangkal silau. Atau topi tikar lebar, pemetik teh tahu, apatunamanya, caping. Main lompat kodok, lompat tali, petak umpet. Harap tertib, jangan dorong2an sikut2an senggol2an 
seperti tadi. Aku senang dengan gerak tanganku: dari kiri geser ke kanan, turun, kiri ke kanan, di atas permukaan elicin kertas. Seperti menggelincir di perosotan, main ayunan. Banyak maaf aku mesti agak mengecilkan ukuran kalian, soalnya kertasku sisa dua setengah, padahal teman-temanmu masih banyak. Para penenun kenangan, peramal pengetahuan, perangkai bayangan. (Ini dari saluran apa? Lupa.)"

Huruf-huruf menjadi kata-kata dan menjadi kalimat-kalimat tersusun karena hubungan dan regularitas atas hubungan-hubungan ini. contoh tulisan Anya adalah contoh yang menarik semua katakata yang terbaca menjadi terhubungkan oleh ingatan dalam lupa.

"huruf-huruf kecil Bisa ditemui di taman bermain, komidi putar, dan hampir seluruh isi buku2. di dunia huruf, anak-anak ini adalah sebagian besar populasi. kecilkecil, tak banyak mengambil tempat, berbaris menempati setengah ruang, cuma sepinggang. seperti tak penting tapi kalianlah pembentuk hampir seluruh isi buku. kubayangkan kalian sebagai ular-ularan panjang anak-anak di belakang peniup suling hamelin, menandak dan menari dalam barisan. main bergerombol, asyik sendiri, cemerlang, bergerak, selalu bergerak. selincah lesat kadal, selamban penyu atau semurung burung yang sedang kembung.

semua kalian telah terlatih menerjemahkan nada suling, sapuan gelap pada terang. kalian pastilah bersepatu adidas, dan kalau diminta dengan manis, akan fasih menderetkan puisi dan nama e.e. cummings. belum kenal dosa huruf besar, tapi diharuskan beriang-riang dalam permainan ciptaan mereka. sebagian besar bentukmu bundar dan gendutgendut, kalaupun berujung tajamtajam tapi ramah-tamah, tidak berbahaya. ada yang berbentuk sangat mirip ibunya, kloning sempurna. ada pula yang tak kepingin mirip wujud besarnya, dengan keras kepala mendirikan identitas yang berbeda sama sekali. bisa dibilang anak-anak ini punya pendirian. yang agak mengkhawatirkan adalah regu yang menempel dengan huruf besar di awal kalimat, kalian kukhawatirkan sangat terpengaruh si huruf besar. pesanku: jangan terkecoh!"

Contoh ini adalah tulisan bukan prospectus yang manjadi prospectus. Huruf kecil menjadi nominee. Mereka lebih bisa handal karena akumulasi mereka tanpa mendesak huruf capital.

"HURUF-HURUF BESAR BISA

DITEMUI PADA KEBANYAKAN PAPAN IKLAN, GARDA DEPAN, NAMA-NAMA PENTING.

MEREKALAH PARA

PENGENDALI, PARA

PENGAWAL DI BERANDA, PEMBERI PERINTAH DI BALIK MEJA MARMER, PEMBERI MODAL, PENYERU PERANG ATAU PENCETUS DAMAI, PENCIPTA DAN PEMENCET TOMBOL PELURU KENDALI POLITIKUS TAKTIKUS KHAOTIKUS. MEREKA PARA PAHLAWAN GAGAH BERANI DI GARIS DEPAN YANG TAK MATI-MATI, PULANG MEMAMERKAN $B A N Y A K$ MEDALI DAN EMBLEM WARNA-WARNI. 
SETIAP MEREKA TERLAHIR DENGAN RASA PENTING DALAM WUJUDNYA. TAKDIR MEREKA NISCAYA BERURUSAN DENGAN YANG AWAL, YANG AGUNG, YANG AKBAR, YANG MEGAH. MEREKA ADALAH PARA PENDAHULU, HAMPIR SELALU MENGAMBIL TEMPAT DI AWAL KALIMAT2, JUDUL2 BUKU, MAKALAH SEMINAR, DISERTASI, GELAR DOKTOR. SETIAP MEREKA BERKELAMIN GANDA ANDROGINI.

HURUFRODIT. BUBUK SARI YANG MEM/DI/PERANAKKAN DIRI SENDIRI TANPA BANTUAN ANGIN. SANG PENIUP SULING HAMELIN YANG ULUNG MENGGIRING YANG KECIL-KECIL DALAM PERMAINAN BESAR,

MENGEKOR PANJANG. SUKA BERSEKUTU DENGAN SESAMA YANG BESAR: UNTUK MENEKANKAN, MEMENTINGKAN, MENGGENTINGKAN, MENYERUKAN DENGAN GEMA NYARING KE PENJURU2. HEGEMONIK DEMONIK. MEREKA PEJABAT TERAS BERJAS BERAMBUT LICIN, MENEBAR NYALANG AURA SUPERIORITAS KE SEKITAR. MANSET MEREKA SENJATA RAHASIA BERBAHAYA ALA NINJA, BERDAYA SABET KE MANA-MANA. ASAL TAHU SAJA, AKU TAK SUKA HURUF BESAR."

Huruf-huruf besar ini adalah penguasa kapitalis. Seiring ingatan anya semua huruf kapitalis memang berada dalam kuasa capital, kota dan kuasa ekonomi. Pengusahapengusaha atau penguasa-penguasa yang memang bertempat di wilayahnya. Yang tidak prospectus disini menjadi calon prospek yang baru. Mereka ada dibalik kejayaan huruf computer di sisi lain kertas. Setidaknya tulisan Anya di dalam mobil ini adalah kejayaan baru hrufhuruf kecil dan besar.

"ANYA asyik menulis, terus menulis, entah telah berapa lama. Hanya ada ia; satu benak, lima jari, dua puluh tujuh huruf abjad anak-beranak. Hingga suatu saat fotokopian satu bab di tangannya kehabisan kertas kosong. Ia membolak-balik berkas, menatap cetakan rapi huruf-huruf komputer sambil bergumam menyumpahi mereka, lalu mulai menulis dalam gerak melingkar searah jarum jam, memenuhi ruang kosong marjin kertas. Ia merasa terganggu dengan logo perusahaan yang selalu tertera di tiap halaman, sangat mengusik simetri hurufhurufnya.

Anya asyik menulis, terus menulis, hingga suatu saat benar-benar kehabisan kertas. Segenap ruang putih kosong pada berkas telah penuh terisi. Ia mengobrak-abrik tas, mencari kertas atau apapun permukaan kosong yang bisa ditulisi. Ia menemukan sejumlah bon belanjaan, struk ATM, dan beberapa benda lain yang bukan kertas tapi bisa mengertas.

Anya kembali asyik menulis, terus menulis, hingga ada suatu bunyi-bunyian mampir di telinganya. Anya menghentikan gerakan bolpen pada bon panjang swalayan, mengangkat muka menatap dunia. Anya memiringkan kepala, sesaat menerka itu bunyi apa. Dengan 
jitu ia menebak asal bunyi dan meraih tas yang terkuak di jok samping. Ia membongkari tas di pangkuannya, mencari teleponjarang-genggam yang rupanya semalam lupa dimatikan. Matanya menyapukan tatap sekilas pada huruf-huruf di dalam semesta tas. CadburyLip Butter White ChocolateNOKIA—calling-Ale...."

Sisi lain kertas adalah kegilaan menari-nari. Ketika menulis tiada memaksakan keteraturan maka menulis menjadi keliaran kegilaan atas tidak berlakunya kuasa dan relasi-relasi kuasa yang terbaca, berbunyi, dan menuntut dalam sebuah dunia. Dunia itu ada di sebalik kertas lain yang Anya sumpahi dan serapahi.

Dalam paparan Derrida mengenai differance, beliau bukan sedang membuat konsepsi efek permainan konsep atau kata untuk sebuah perwujudan verbalisasi dan nominalisasi. Bukan proses penjelasan dan pembentukan konsep dan kata itu sendiri. Seperti halnya dalam prinsip Hegelian, differance tak ter-terjemahkan, tak terdefinisikan, tak ter-pikirkan. Differance juga tidak bisa dipikirkan lewat ontology apapun sehingga menjadi kata, konsep, atau kunci yang berkuasa atas makna. Difference hanya dituliskan, dipahami ada dalam jaringan lewat "rantai konsep-konsep dan kata-kata lain". kata dan konsep saling berkonfigurasi, berkedudukan dalam sebuah teks, dan dalam konfigurasi teks yang lain. mereka ada dalam keberadaan mereka dalam sebuah teks. Singkatnya tidak ada yang konkret atas konsep dan kata.

"The motif of differance, when marked by a silent a, in effect plays neither the role of a "concept," nor simply of a "word." ... This does not prevent it from producing conceptual effects and verbal or nominal concretion."

"SEPERTI Ale dan Anya. Kedua huruf menari-nari jumpalitan dalam benaknya saat ia menyeruak naik dari balik setir. Telapak tangannya terasa agak nyeri, ia telah terlalu bersemangat mencengkeram bolpen hingga kuku-kukunya seperti menjelma belati menikam telapak. Sensasi agak nyeri itu bertambah dengan pegal. Anya melemaskan jari-jari, mengangkat muka menatap dunia di luar bentangan kaca depan mobil."

Wacana seksualitas muncul karena bayangan huruf $\mathrm{B}$ yang terdiri dari D. mereka bersetubuh melahirkan huruf d kecil. Seksualitas macam ini adalah persetubuhan Anya dan Ale. Keluar dari regulasi kuasa karena seksualitas seharusnya diluar regulasi relasi kuasa. Kota dan keteraturan adalah bentuk kuasa yang menghalangi seksualitas atas lambang B dan dua buah D yang bersetubuh melahirkan anak d yang kecil.

"Di seberang jalan tampak sehelai spanduk. Mungkin berisi sebuah ajakan untuk menyukseskan, memberantas atau mengentaskan sesuatu. Anya tak membaca isinya, tetapi hanya melihat bentukbentuk huruf hitam pada kain kuning."

Bukti bahwa regularitas selalu menekan dan menata. Namun regularitas yang menata itu hanya bunyi saja ketika dibaca dalam wacana kegilaan. 


\section{Telaah Syam}

Syam bukan Syria. Lagipula Syam ini bukan sebuah negeri dengan terik matahari. Namun Syam diperbandingkan dengan sebuah negeri matahari. Atau sosok ini adalah persona yang disebut sebagai antitesis dari segala hal yang menerangi. Ia bukan simile apapun. Namanya benar-benar lawan dari maknanya sendiri. Oleh karenanya, ia tidak pernah menjadi sentral dari pengetahuan.

Sebagaimana pengetahuan yang selalu memberikan pencerahan, Syam adalah kegelapan. Narasi ini dimulai dengan sebuah tesis unik, seseorang atau sosok gelap mengamati terang.

Jika ada sebuah dunia yang diterangi matahari, maka ada pula keadaaan lain diluar bumi dan matahari yakni kegelapan. Pada saat siang ini kegelapan tetap hidup mengamati dialektika terang bumi oleh matahari.

"SYAM, tak seperti namanya, bukan seorang matahari. Ia antitesis cahaya dan segala yang terang. Semisal lukisan, ia bukan figur di tengah yang terangbenderang berdiri gagah berkacak pinggang, namun siluet gelap berjubah hitam yang bersandar di sudut. Siluet yang mengamati segala di sekitar, di dalam dan di luar lukisan."

Derrida menyatakan berbahaya logosentrisme. Logosentrisme merupakan situasi ketika manusia tidak menggunakan pemikiran mereka sendiri karena manusia mengikuti asumsi dari konsep yang sudah ajeg. Konsep ini memusat. Manusia seiring dengan ide dan konsepnya memusatkan halhal dasar sampai semuanya menjadi referensi yang prinsip. Pusat kemudian mengenali konsep sebagai kebenaran. Kebenaran ini terdiri atas peraturan, sistem, dan anasir-anasir struktural. Dinyatakan bahwa dalam kenyataannya, konsep seperti sistem ini hanya fiksi. Segala hal yang kita sebut pusat agaknya menjadi subdivisi dari pusat yang lain. Dalam dekonstruksi, Derrida menyatakan bahwa tidak ada pusat karena ada kemungkinan pusat ini adalah sisi lain dari pusat yang lain. lebih lanjut, ia menegaskan bahwa seluruh sistem ini hanya fiksi karena apa yang orang pikirkan tentang unsur-unsur yang membangun pusat yang mungkin menjadi pusat lain yang tentu terdiri dari unsur-unsur lain juga. Syam seorang ironis sejati, bicaranya kerap tampak berlawanan dengan akal sehat banyak manusia. Sebagaimana dekonstrusi selalu mempertanyakan jejak-jejak permanen.

"Ia makan tiga kali sehari hanya jika sedang bersama ketiga sahabatnya-Batara, Anya, dan Ale. Syam lebih suka mengurung diri membaca buku. Begitu banyak buku dihabiskan dalam kecepatan di atas rata-rata orang. Ia suka mengutip perkataan atau tulisan siapalah yang sesuai kesempatan apalah-sering ia lakukan untuk sekadar menjengkelkan ketiga temannya. Ia mengutip Heraklitus atau Konfusius, Isutzu dan Lao Tzu, Charles atau Jean Fourier, Ibnu 'Arabi dan Hammurabi, Novalis, dan sejumlah novelis. Juga Rilke dan Roethke, atau penyair Cina dinasti Tang dan penyair Polandia pascaperang."

Jejak-jejak Syam memang permanen pada awalnya dengan keterbacaannya pada buku-buku dari tokoh-tokoh berpengaruh di 
sepanjang dunia. Namun Syam berubah.

"Di akhir 2005, tiba-tiba segala berubah. Sesuatu telah mengubah Syam luar-dalam. Sesuatu yang biasa terpandang mata, namun mampu membelokkan dan menekuk takdir seseorang dengan teramat fatal. Sesuatu yang akan sangat dikenali seseorang, takkan pernah tampak sama di matanya, menjelma doa dan mimpi buruk, membayang pada benda yang disentuh dan wajah yang ditatap, melekat di langkah kaki sepanjang jalan. Adalah air yang telah meredupkan matahari dalam diri Syam. Matahari yang dulu tak garang kini tinggal temaram."

"Ini kampung yang pernah. Jalanan yang pernah. Aku mencari jejak rumahku. Jalanan penuh puing dan rangka bangunan, lumpur serupa enamel yang melapisi semua yang pernah. Semacam bebauan bergerak di udara, di atas kelupas aspal dan gelimpangan mayat."

Sebagaimana dikatakan Foucaut segala macam klaim kebenaran adalah interpretasi atas sebuah dunia, yang sebenarnya tidak ada sebagai sesuatu yang historis. Peristiwa hanya pernah namun tidak lagi terjadi sekarang. Keadaan selalu berubah adaah kuasa dari perubahan itu sendiri. Menurut Foucault, kekuasaan ada di mana-mana, karena kekuasaan adalah satu dimensi dari relasi. Di mana ada relasi, di sana ada kekuasaan. Segala latar yang pernah ada ini menjadi mayat yang berbau dan kemudian dihindari. Oleh karenanya harus ada perubahan atas latar. Syam menghindari peristiwa lalu di kampung halamannya dan bergerak pada kebaharuan.

Kesadaran Syam adalah kekuasaan yang menjadi strategi. Karena tidak ada lagi strategi baku yang memusat maka Syam harus menciptakan strategi kuasa ini dalam dirinya. Foucault mengatakan strategi ini bisa berlangsung di manamana dan menciptakan sistem, aturan, susunan dan regulasi yang baru. Kekuasaan ini tidak datang dari luar, melainkan kekuasaan menentukan susunan, aturan dan hubungan-hubungan dari dalam dan memungkinkan semuanya terjadi, dalam diri Syam.

"Kukenali masjid. Empat dinding putihnya masih berdiri tegak menandu kubah, tak berpucuk. Di halaman masjid, seseorang berwajah putih mengangkat bulan sabit dan bintang jatuh. Di langit, matahari seperti daun melayang. Pecahan kaca dan patahan kayu timpa-menimpa dengan pohon tumbang dan bongkah beton di mana-mana.Tak jauh dari masjid, kedai nasi yang pernah. Tempat aku dan ayahku duduk minum kopi di sore-sore hari seusai mengaduk semen dinding mesjid bertahun lalu."

"Ruang temaram sempurna, hening begitu lama. Di suatu saat, manusia temaram bersuara. Suara Syam lamat-lamat mengalir ke telinga Anya, satusatunya manusia di dunia yang ia ceritakan tentang mimpi itu. Anya merasakan denyut jantung di dada Syam, setiap hirup nafasnya. Syam merasakan basah mengumpul di bahu 
kemejanya. Tetes peluhnya, linang air mata Anya, apa bedanya. Anya masih tak bicara apa-apa hingga Syam selesai bicara dan ruangan kembali hening. Mereka berbaring seperti itu sepanjang sisa malam.

Narasi-narasi Amal memang bermuatan ekspermentasi dari bentuk narasi yang sukar dipahami. Wacana dalam cerpen-cerpen ini terkait dengan dekonstruksi lewat tokoh dan kepenulisan. Huruf, kata dan narasi dalam sebuah teks sastra tak perlu bermakna. Tak ada satupun huruf yang menguasai dirinya sendiri, atau kata-kata yang dibentuknya. Kata dalam teks bisa mengabaikan regulasi makna. Kata meninggalkan kenyataan dan regularitas makna yang dimaksudkannya. Kemudian absurdisme mengalir berdasar pada kepercayaan ke-tak berarti-an, walau pada dunia regular narasi. Difference menjadi konsepsi efek permainan konsep atau kata untuk sebuah perwujudan verbalisasi dan nominalisasi. Cerpen bercerita mengenai absurditas pada sebuah latar.

Jatuh cinta merupakan perjumpaan. Anya dan Syam berjumpa dengan banyak hal dalam bentuk huruf dan bunyi. Tak ada yang bermakna dalam perjumpaan ini. hanya ada kegilaan, keisengan, dan keseksian kesadaran atas sebuah dunia baru. Dunia sisi-sisi kertas, waktu akhir pekan, diluar tatanan. Mungkin jatuh cinta itu ada pada pandangan pertama. Keterpikatan pada suatu bentuk yang tak perlu berfungsi; walau sebenarnya hal tersebut bisa berfungsi. Akan tetapi saat akhir pekan fungsi harus diubah menjadi bentuk lain yang tak berfungsi. $\begin{array}{llr}\text { Cermin } & \text { menjadi } & \text { symbol } \\ \text { pertemuan. } & \text { Awal dari narasi }\end{array}$ memperhatikan fungsi yang tak berfungsi. Cermin bisa menjadi teladan dan bisa memberikan bayangan dari perasaan hati. Namun keteladanan atas bayangan tidak bisa memulai hari Anya.Kesenangan merupakan prinsip dari kegialaan. Ketika aturan dibuat untuk bertindak dan berlaku kini hanya bagian dari tertawaan. Tidak ada yang memandu dari segala hal yang tertulis. Semua hanya bagian dari kesenangan dan keisengan. Aksi harus dilakukan karena masih ada kesadaran dalam diri. Absurdisme mengalir berdasar pada kepercayaan ke-tak berarti-an. Semua hal harus tidak masuk akal. Tata tertib menyadarkan bahwa semua berbenturan satu sama lain dengan kepentingan lain, dan bagi masyarakat lain. Kembali kepada dunia absurd dan kembali pada dunia regular adalah bagian narasi yang disajikan. Hanya yang lebih mengemuka, absurditas bisa terlaksana dan mengejawantah karena hari ini hari sabtu. Akhir minggu memang seharusnya waktu ketika manusia meninggalkan normalitas.

Huruf-huruf menjadi kata-kata dan menjadi kalimat-kalimat tersusun karena hubungan dan regularitas atas hubungan-hubungan ini. contoh tulisan Anya adaah contoh yang menarik semua katakata yang terbaca menjadi terhubungkan oleh ingatan dalam lupa. Huruf-huruf besar ini adalah penguasa kapitalis. Seiring ingatan Anya semua huruf kapitalis memang berada dalam kuasa capital, kota dan kuasa ekonomi. Pengusahapengusaha atau penguasa-penguasa yang memang bertempat di wilayahnya. Yang tidak prospectus 
disini menjadi calon prospek yang baru. Mereka ada dibalik kejayaan huruf computer di sisi lain kertas. Setidaknya tulisan anya di dalm mobil ini adalah kejayaan baru hrufhuruf kecil dan besar. Mereka mengisi sisi lain kekuasaaan. Huruf dan kata tertulis hanya karena ingatan keterbacaan, bunyi, keliaran huruf untuk menjadi kata. Anya menjadi penguasa baru keliaran huruf kecil dan besar di sisi lain kertas.

Sisi lain kertas adalah kegilaan menari-nari. Ketika menulis tiada memaksakan keteraturan maka menulis menjadi keliaran kegilaan atas tidak berlakunya kuasa dan relasi-relasi kuasa yang terbaca, berbunyi, dan menuntut dalam sebuah dunia. Dunia itu ada di sebalik kertas lain yang Anya sumpahi dan serapahi. Dalam paparan Derrida mengenai difference, hal ini tak terterjemahkan, tak ter-definisikan, tak ter-pikirkan. Differance juga tidak bisa dipikirkan lewat ontology apapun sehingga menjadi kata, konsep, atau kunci yang berkuasa atas makna. Difference hanya dituliskan, dipahami ada dalam jaringan lewat "rantai konsep-konsep dan kata-kata lain". kata dan konsep saling berkonfigurasi, berkedudukan dalam sebuah teks, dan dalam konfigurasi teks yang lain. mereka ada dalam keberadaan mereka dalam sebuah teks. Singkatnya tidak ada yang konkret atas konsep dan kata. Bukti bahwa regularitas selalu menekan dan menata. Namun regularitas yang menata itu hanya bunyi saja ketika dibaca dalam wacana kegilaan.

Lewat cerpen Syam ada sebuah dunia yang diterangi matahari, maka ada pula keadaaan lain diluar bumi dan matahari yakni kegelapan. Pada saat siang ini kegelapan tetap hidup mengamati dialektika terang bumi oleh matahari. Derrida menyatakan berbahaya logosentrisme. Logosentrisme merupakan situasi ketika manusia tidak menggunakan pemikiran mereka sendiri karena manusia mengikuti asumsi dari konsep yang sudah ajeg. Konsep ini memusat. Manusia seiring dengan ide dan konsepnya memusatkan hal-hal dasar sampai semuanya menjadi referensi yang prinsip. Pusat kemudian mengenali konsep sebagai kebenaran. Kebenaran ini terdiri atas peraturan, sistem, dan anasir-anasir struktural. Dinyatakan bahwa dalam kenyataannya, konsep seperti sisitem ini hanya fiksi. Segala hal yang kita sebut pusat agaknya menjadi subdivisi dari pusat yang lain. Dalam dekonstruksi, Derrida menyatakan bahwa tidak ada pusat karena ada kemungkinan pusat ini adalah sisi lain dari pusat yang lain. lebih lanjut, ia menegaskan bahwa seluruh sistem ini hanya fiksi karena apa yang orang pikirkan tentang unsur-unsur yang membangun pusat yang mungkin menjadi pusat lain yang tentu terdiri dari unsur-unsur lain juga. Syam seorang ironis sejati, bicaranya kerap tampak berlawanan dengan akal sehat banyak manusia. Sebagaimana dekonstrusi sealu mempertanyakan jejak-jejak permanen.

Sebagaimana dikatakan
Foucaut segala macam klaim
kebenaran adalah interpretasi atas
sebuah dunia, yang sebenarnya tidak
ada sebagai sesuatu yang historis.
Peristiwa hanya pernah namun tidak
lagi terjadi sekarang. Keadaan selalu
berubah adaah kuasa dari perubahan
itu sendiri. Menurut Foucault,


kekuasaan ada di mana-mana, karena kekuasaan adalah satu dimensi dari relasi. Di mana ada relasi, di sana ada kekuasaan. Segala latar yang pernah ada ini menjadi mayat yang berbau dan kemudian dihindari. Oleh karenanya harus ada perubahan atas latar. Syam menghindari peristiwa lalu di kampung halamannya dan bergerak pada kebaharuan. Kesadaran Syam adalah kekuasaan yang menjadi strategi. Karena tidak ada lagi strategi baku yang memusat maka Syam harus menciptakan strategi kuasa ini daam dirinya. Foucault mengatakan strategi ini bisa berlangsung di mana-mana dan menciptakan sistem, aturan, susunan dan regulasi yang baru. Kekuasaan ini tidak datang dari luar, melainkan kekuasaan menentukan susunan, aturan dan hubungan-hubungan dari dalam dan memungkinkan semuanya terjadi, dalam diri Syam.

Kesosokan dari seorang tokoh antihero dalam wacana absurditas. Antihero adalah individu yang tidak lagi mampu memenangi moralitas yang selalu melingkungi manusia. Sosok ini telah terlanjur menjadi keturunan yang tidak bisa menghindari Freudanisme, dalam keterkaitannya dengan kehidupan yang berhubungan dengan ide-ide psikoanalisis dan existensialisme yang menganggap manusia bebas. Jika sifat naluriah seseorang yang mengolok-olok segala kepura-puraan terhadap kepastian moral, maka heroisme - bagi para pemaham absurditas - hanya akan menjadi produk yang dirasionalisasi oleh muslihat yang dicipta oleh diri sendiri atau oleh kuasa diri sendiri. Berdasar pada pemahaman Gordon ini pemahaman manusia atas sebuah narasi besar bisa diperlawankan dengan pemahaman lewat absurditas. Pemahaman absurd ini tentu harus inkonsisten dengan akal, logika, dan keumuman.

Narasi-narasi Amal memang bermuatan ekspermentasi dari bentuk narasi yang sukar dipahami. Gaya tulisan ini disebut eksperimental sebagaimana pernah menjadi tren di tahun 1950an hingga 1960an (2002: 6). Formula narasi dibuat bergenre picaresque. Narasi ini mengabaikan isu-isu psikologis dan filosofis. Ada cara tertentu yang dipilih dalam genre ini; misalnya dengan mengalineasi tokoh yang dianggap hero dalam sebuah cerita. tokoh Anya dan Syam tidak perlu lagi diperkarakan sebbagai tokoh utama karena tokoh-tokoh ini pun dikarakterisasi sedemikian rupa dengan kebingungan mereka atas latar di dunia mereka. Sebagaimana Gordon memaparkan bahwa (2002: 57-58) paradoks absurdisme, seperti juga eksistensialisme, menuntut dimensi eksistensial atas tegangan antara perjanjian dan ketidakmampuan, dan juga antara logika dan absurditas. Kewaspadaan atas kehidupan menjadi tak bermakna. Ketidakbermaknaan hidup ini ketika ditempatkan pada saat pikiran manusia mengalami reses; manusia ingin sesaat berhenti berpikir atau memikirkan sesuatu. Manusia pada satu saat ingin hidup dengan sesungguhnya tanpa perasaan tertentu.

\section{SIMPULAN}

Wacana dalam cerpen-cerpen ini terkait dengan dekonstruksi lewat tokoh dan kepenulisan. Huruf, kata dan narasi dalam sebuah teks sastra tak perlu bermakna. Tak ada satupun huruf yang menguasai dirinya sendiri, atau kata-kata yang 
dibentuknya. Kata dalam teks bisa mengabaikan regulasi makna. Kata meninggalkan kenyataan dan regularitas makna yang dimaksudkannya. Kemudian absurdisme mengalir berdasar pada kepercayaan ke-tak berarti-an, walau pada dunia regular narasi. Difference menjadi konsepsi efek permainan konsep atau kata untuk sebuah perwujudan verbalisasi dan nominalisasi. Cerpen bercerita mengenai absurditas pada sebuah latar.

Dalam beberapa hal mengenai dekonstruksi, baik Derrida atau Foucault memberikan sisi lain pembacaan atas teks narasi. Yang mungkin belum bisa muncul dalam tulisan ini adalah konstruksi lain yang ajeg ketika konstruksi ini adalah penghindaran dari sebuah konstruksi lain yang dianggap pusat.

Lewat telaah atas dua cerpen Nukila Amal ini, pembacaan secara dekonstruktif memberikan hal lain sebuah pemahaman atas dunia. Namun tidak berarti bahwa ada kepastian bahwa Nukila Ama berpandangan yang sama sebagaimana tulisan ini. Dari ketidakpastian pandangan ini, maka tulisan ini di akhir ingin menyarankan hal atas kepastian mengenai bagaimana membaca teks benar-benar menjadi seiring dengan kepenulisan dari teks itu sendiri.

\section{REFERENSI}

Amal, Nukila. 2010. Hari Anya Jatuh Cinta (Koran Tempo, 29 Agustus 2010)

Amal, Nukila. 2010. Syam (Koran Tempo, 29 Agustus 2010)

Amal, Nukila. 2005. Laluba: Kumpulan Cerita Pendek Alvabet.
Davis, Robert Con \& Schleifer Roland. 1994. Contemporary Literary Criticism:Literary and Cultural Studies. London: longman Publisher.

Eagleton, Terry. 1996. Literary Theory: An Introduction (2nd edition). Massachusetts: Blackwell Publishers.

Fanon, Frantz. 1961. The Wretched of the Earth. San Diego: Penguin.

Foucault, Michael. 2012. The Archaeology of Knowledge. Trans. Inyiak Ridwan Munir. 1st ed. Jogjakarta: IRCiSod,

Gordon, Lois. 2002. Reading Godot. New Haven and London: Yale University Press.

Hodges, Ian. 2002. Moving Beyond Words: Therapeutic Discourse and Ethical Problematization. Discourse Studies_4(4): 455479

Keith, Booker, M. 1996. A Practical Introduction to Literary Theory and Criticism. New York: Longman Publisher.

Mardiana, Ninik. 2009. "Analisis Dekonstruksi Derrida Terhadap Sistem Stratifikasi Sosial Bali Dalam Karya-Karya Oka Rusmini." Malang: Universitas Negeri Malang.

Pasaribu, Adrian Jonathan. 2011. "Dekonstruksi Nilai-Nilai Keluarga Dalam Film Noir: Analisis Struktur Naratif Double Indemnity, the Postman Always Rings Twice, Dan Kiss Me Deadly." Yogyakarta: Universitas Gadjah Mada.

Rajagopalachari, C. 2008. Mahabarata: Kisah Epos Sepanjang Zaman: Sebuah Epik Pencerahan Jiwa Manusia. Jogjakarta: IRCisOd. 